\title{
Editorial: Journal of Interaction Science
}

\author{
Gisela Susanne Bahr
}

\section{Dear Readers,}

Welcome to the Journal of Interaction Science (JoIS)!

It's taken us a little over 2 years from the idea to the launch and you can imagine there are lots of stories and anecdotes to fill many pages. However, being a responsible editor in chief, I'll spare you the reminiscences. At the same time, (you have guessed my agenda) I hope that a brief editorial has a better chance of being read.

Why did we start this journal? The Journal of Interaction Science is a necessity that grew out of frustration. If you walk into a room with some of the many experimental, cognitive psychologists at a Human Computer Interaction (HCI) conference, you can hear them complaining passionately. In fact, they untiringly bemoan their observation that research on HCI lacks methodological rigor. "These studies could advance our knowledge of human cognition and of the unquestionable impact of technology on cognition and behavior, if only, if only, they were done right!" This point of view seems disconcertingly arrogant. However, it is the nature of radical positions to energize new ways of thinking and change. This is what gave JoIS its impetus.

Dr. Ray Adams, then professor at Middlesex University, London, developed the JoIS idea. I am like Ray, a cognitive, experimental psychologist, who similar to our colleagues likes to complain now and then but inevitably stops and works to solve the problem. Therefore, I helped Ray during the process but it is to Ray's credit that Springer decided to take on our radical and new Journal. Their help has been invaluable in getting JoIS launched: I must thank two people especially: the incredibly resourceful Rachel Roberts and the utterly amazing Bev Ford!

What makes JoIS radical and new?

Our world is replete with interactive devices. It is evident that humans are prolific and always ready to invent, build and buy the next break-through, interactive device. At the point that I am writing this editorial, over 10 million preorders for the Galaxy S4 smart phone (complete

Correspondence: gbahr@fit.edu

PhD Experimental Psychology-Cognition, Doctoral candidate in Computer Sciences, Florida Institute of Technology, Melbourne, Florida, USA with gesture recognition and eye tracking capabilities) have been placed according the official Samsung wikipage. "Wow! [sic]". There seem to be no end in sight of technologies that are intended to improve our work, schools and personal lives, our health and governments. Let's hope they do! But let's be serious; there are many aspects to technology development, but for JoIS our focus is obvious: We are concerned not with challenges of making technology work, but with the challenges of making technology work for humans and how this technology affects us every day and throughout our lifetimes.

Building technology is an engineering problem and developing any sophisticated interactive device is a complex task; but, it is solvable. On the other hand, understanding and predicting what works for individual humans and how it affects each one of us seems to be an intractable problem because of the exponential number of possible outcomes. The people trained in the methods to study human cognition and behavior experimentally are research psychologists (not our clinical colleagues). However, the majority of researchers in the traditional disciplines of psychology awkwardly turn their heads the other way when questions are asked about human cognition and behavior in the context of daily, hourly or by the minute exposures to technology. Perhaps this proverbial shoulder-shrugging is the result of the astonishing speed of tech innovation, a firm but false belief that humans are impervious to the impact of technology or the inability to collaborate with engineering communities. Regardless of the reasons, they don't justify (a) ignorance of the powers and influences of technology in our everyday lives and (b) an enormous research deficit and (c) dismissal of research efforts and opportunities.

Isn't there anybody who cares about the psychological core of interaction science? We may turn to software and hardware developers who pay attention to human interaction components in order to improve the usability and market share of a product. Clearly, the pressure of economy and delivery schedules place real limitations on their capacity to do research with the tools they develop. Usability is an important aspect of HCI but only a small part of Interaction Science. The majority of interaction 
science work is distributed all over the world but without a well-known port of call.

This is where JoIS fits in.

JoIS is grounded in empiricism and employs the best of psychology, its experimental methodology and statistics. We believe that rigorous research methodology is the marlin spike that can unravel the convoluted knot of interactions between humans and the technologies that they have created. Our goal is to attract and publish scientific investigations of human interactions with modern technologies, including their potential for bringing about change, their limitations, their benefits, their consequences and their broader impact.

It follows that the definition of what we do is in the papers we publish: JoIS and its authors advance interaction science using the TEAM approach: Theory advancement, Empirical advancement, Applied advancement, Methodological advancements.

For our launching issue we have two papers that target methodology:

In their paper "Open Source Accessibility - A Short Case Study in Risk management" Michael Heron and colleagues bring together the disciplines of computer sciences and interaction R\&D. They present opportunities, limitations and security considerations of the open source approach in the development and maintenance of accessible interface. The idea of the Opensource software (OSS) model took form in the 1980s and includes principles such as security, affordability, transparency, perpetuity and interoperability and being free of charge. In this model the OOS copyright holder grants the rights to study, modify and distribute the software for free to anyone and for any purpose. Clearly the opportunities from OOS are vast. Heron and colleagues carefully examine to what extend accessibility software can benefit from this model and discuss safeguards and limitations.

Likewise, Rachel Harrison and colleagues' paper focuses on advancing methodology: The authors present a new framework for mobile device usability evaluation that takes a diversity of user contexts and concurrent user tasks into consideration. They report that usability is usually measured in terms of three attributes; effectiveness, efficiency and satisfaction but that other, obvious attributes, such as cognitive load, tend to be overlooked. To remedy this state they introduce the PACMAD (People At the Centre of Mobile Application Development) model specifically for use with mobile devices. PACMAD brings together significant attributes from different usability models in order to create a more comprehensive model ready for research deployment.

I promised you to keep it short and in the best academic traditions I have rambled on for two pages single space already!
All left to say is this:

Please join us for our first issue!

Please consider JoIS for your next submission and feel free to include multimedia content!

Last but not least,

Check out our research methods blog http://blogs. springeropen.com/jois/.

In our blog, we will explore the breadth and depth of research methods with humans. It combines theory with practice giving useful "how-to" and "better-not-do-that" thought that may help prevent some embarrassment not only for junior investigators ;-)

Consistently warm regards from Florida,

\section{G.S. Bahr}

Editor in Chief

Journal of Interaction Science

Received: 3 May 2013 Accepted: 3 May 2013

Published: 8 May 2013

doi:10.1186/2194-0827-1-3

Cite this article as: Bahr: Editorial: Journal of Interaction Science. Journal of Interaction Science 2013 1:3.

\section{Submit your manuscript to a SpringerOpen ${ }^{\circ}$ journal and benefit from:}

- Convenient online submission

- Rigorous peer review

- Immediate publication on acceptance

- Open access: articles freely available online

- High visibility within the field

- Retaining the copyright to your article

Submit your next manuscript at springeropen.com 